\title{
Correction to: Expressive language sampling as a source of outcome measures for treatment studies in fragile $X$ syndrome: feasibility, practice effects, test-retest reliability, and construct validity
}

\author{
Leonard Abbeduto ${ }^{1 *}$, Elizabeth Berry-Kravis², Audra Sterling ${ }^{3}$, Stephanie Sherman ${ }^{4}$, Jamie O. Edgin ${ }^{5}$,
} Andrea McDuffie ${ }^{1}$, Anne Hoffmann ${ }^{2}$, Debra Hamilton ${ }^{4}$, Michael Nelson ${ }^{2}$, Jeannie Aschkenasy ${ }^{2}$ and Angela John Thurman ${ }^{1}$

Correction to: J Neurodevelop Disord (2020) 12:10 https://doi.org/10.1186/s11689-020-09313-6

In the original publication of this article [1], the author name Leonard Abbeduto was misspelled as Leonardkk Abbeduto. The original article has been corrected.

The publisher apologizes for the inconvenience this has caused.

\section{Author details}

${ }^{1}$ UC Davis MIND Institute and Department of Psychiatry and Behavioral Sciences, University of California, 2825 50th St. Davis, Sacramento, CA 95817, USA. ${ }^{2}$ Departments of Pediatrics, Neurological Sciences and Biochemistry, Rush University Medical Center, Chicago, USA. ${ }^{3}$ Waisman Center and Department of Communication Sciences and Disorders, University of Wisconsin-Madison, Madison, USA. ${ }^{4}$ Department of Human Genetics, Emory University, Atlanta, USA. ${ }^{5}$ Department of Psychology, University of Arizona, Tucson, USA.

Published online: 02 April 2020

\section{Reference}

1. Abbeduto L, Berry-Kravis E, Sterling A, Sherman S, Edgin JO, McDuffie A, Hoffmann A, Hamilton D, Nelson M, Aschkenasy J, Thurman AJ. Expressive language sampling as a source of outcome measures for treatment studies in fragile $\mathrm{X}$ syndrome: feasibility, practice effects, testretest reliability, and construct validity. J Neurodevelop Disord. 2020;12: 10. https://doi.org/10.1186/s11689-020-09313-6.

C C The Author(s). 2020 Open Access This article is licensed under a Creative Commons Attribution 4.0 International License, which permits use, sharing, adaptation, distribution and reproduction in any medium or format, as long as you give appropriate credit to the original author(s) and the source, provide a link to the Creative Commons licence, and indicate if changes were made. The images or other third party material in this article are included in the article's Creative Commons licence, unless indicated otherwise in a credit line to the material. If material is not included in the article's Creative Commons licence and your intended use is not permitted by statutory regulation or exceeds the permitted use, you will need to obtain permission directly from the copyright holder. To view a copy of this licence, visit http://creativecommons.org/licenses/by/4.0/ The Creative Commons Public Domain Dedication waiver (http://creativecommons.org/publicdomain/zero/1.0/) applies to the data made available in this article, unless otherwise stated in a credit line to the data. 